\title{
COMPETITIVE MANAGEMENT STRATEGY FOR PRINT MEDIA ADVERTISING ACTIVITIES
}

\author{
UDC: $070.36: 005$ \\ Original Scientific Paper \\ Marijana VIDAS-BUBANJA ${ }^{1}$, Iva BUBANJA ${ }^{2}$ \\ ${ }^{1}$ Belgrade Business School, 11000 Belgrade, Kraljice Marije 73, Republic of Serbia \\ ${ }^{2}$ Belgrade Business School, 11000 Belgrade, Kraljice Marije 73, Republic of Serbia \\ E-mail: ivabubanja@gmail.com
}

Paper received: 31.10.2015.; Paper accepted: 21.11.2015.

\begin{abstract}
There is a growing trend of transferring commercials from print media to online format during the last decade. Rising number of users who are spending more time on the Internet and social networks, are the main reason why print media are facing a problem of keeping advertisers in their media in order to provide resources for their survival. Newspapers are going through meager changes intending to adapt to business conditions in the digital environment. The conducted research on the sample of ten Belgrade daily newspapers indicate the weaknesses of print media formats and give inputs for the creation of competitive media strategy based on synergy of print and digital formats.
\end{abstract}

Keywords: commercials, print media, online format, newspapers, self-promotion.

\section{INTRODUCTION}

Commercials are devised, planned and paid form of market communication between a producer and a consumer. The main aims of commercials are to inform potential buyers about offered products and services in order to make them interested and persuade them to buy (Potter, 2011). The commercials are one of the main techniques of promotion, which is a part of marketing mix. The promotion represents one of the crucial marketing activities (Kotler, 2004). Marketing influences the exchange of social values and helps people to understand and satisfy their needs. In this way, marketing enables social reproduction (material and spiritual) and forms the base of all economic and social activities (Potter, 2011).

Messages that commercials contain affect the human brain and encourage people to think about the promoted products/services. Good commercial messages emphasize the positive attributes of a product and they are the main reason for an average customer to buy a certain product. The media are transfer channels for commercials to the public. Producers choose different media, which can emphasize products' characteristics in the best possible way.

Different customer target groups and the chosen media characteristics influence the producer's selection of the media. The right choice of media is very important. If a commercial message is transferred to the public by wrong media, the producer risks failure in promotion of its product or service (Jefkins, 2003).

\section{PRINT MEDIA IN MODERN COMMERCIAL PRACTICE}

The media and publishing industry is undergoing a massive transformation thanks to the rise of the Internet and digital media. Traditional revenue models based solely on subscriptions and advertising sales are becoming obsolete as subscription is falling and digital media are presenting fierce competition on advertising market.

Golden Age' for print media was a period between 1890 and 1920, when the industry grew and newspapers enjoyed the attention of being society's primary source of information. However, 
the Great Depression disrupted this and in the 1930s newspapers were severely hurt, hundreds of companies ended operations. This was escalated with the emerging broadcast radio, offering lower priced alternative news and as a result capturing a large portion of advertising revenues from newspapers (Patel, 2010).

Television was the next technology that disrupted the newspaper business. It was a more powerful medium to distribute information and it overtook the newspaper and majority of national advertising in the 1960s. In response, newspapers consolidated and existing newspapers got an opportunity to enjoy a semi-monopolistic position.

However, the early 1990s was the last time newspapers enjoyed profit margins of $20 \%$ to $25 \%$. In 1995, the Internet was introduced to the public and by the millennium the Internet as a worldwide platform became evident. The Internet reached more people than any newspaper had and profits margins have dropped to an average of $5 \%$. The mere ability to access information and receive instant updates threatened the purpose of a newspaper as an information source. In the same time, there is a growing trend of transferring commercials from print media to online format during the last decade. Rising number of users who are spending more time on the Internet and social networks, are the main reason why print media are facing a problem of keeping advertisers in their media in order to provide resources for their survival (Ibidem).

Beside the Internet, economic crises that begun in 2008/9 caused financial challenges for newspapers and created very uncertain environment for print media. The most newspapers were faced with cuts in revenues from declining subscriptions and single copy purchasers. Readers were looking for more cost effective alternatives and as a result increased consumption of online news. Since most newspapers do not charge for their online content, this shift in consumption did not drive any revenue increase for the publishers.

On the other hand, the recession resulted in deep cuts in marketing budgets of the majority of companies. Since the newspaper business model is largely dependent on advertising as a form of revenue, this advertising recession brutally hurt publishers.

In the US, the industry experienced a $23 \%$ fall in advertising revenues in 2007 and 2008 and revenue in 2012 was $45 \%$ of what it was in 2006. Print advertising losses continued to fall which far exceeded digital ad gains. In the US, for example, in 2012 the ratio was about $\$ 15$ print lost for every digital dollar gained. In 2013 according to Newspaper association of America, print advertising revenues fell to $\$ 17.3 \mathrm{~b}$ and they haven't been lower since 1950 (IAB.Europe, 2012a).

Therefore, this overall plunge in revenue forced newspaper publishers to cut costs and scale back operations in order to survive. Internally, publishing houses began to lay-off staff and reduce the number of editors. Overall, the decade-long trend in newspaper job losses continues.

The best example of this growing phenomenon is reduction of US journalists in their print media. According to the annual American Society of Newspaper Editors survey, in the decade from 2003 through 2012, a total of 16,200 jobs were lost. The recession years of 2008 and 2009 took a toll from which the industry never recovered. In 2007, there were 52,600 full-time newsroom employees in US. Two years later, that workforce had been pruned by about $20 \%$ (Kemp, 2014).

\section{RESEARCH PROBLEM}

Daily newspapers are specific media with great circulation and massive and various audience. These characteristics make them an efficient commercial medium. In this paper we describe a case study for Belgrade daily newspaper in which we show what their position on Serbian advertising market is, having in mind raising potentials of the Internet and online advertising. As well as, examining how Belgrade daily newspapers are using self-promotion activities as the best way to increase circulation and to get a loyal audience.

In order to get inputs for the creation of competitive management strategy for print media in advertising activities, we will look at:

- The volume of commercial contents in Belgrade daily newspapers (print and online version),

- The presence of commercials in different types of newspapers,

- Circulation and price as determinants for the competitiveness level of daily newspapers as advertising media,

- The volume of self-promotion contents in Belgrade daily newspapers, 
- The relationship between commercials and selfpromotions in Belgrade daily newspapers,

- The relationship between print and online version of Belgrade daily newspapers concerning commercial and self-promotion contents and finally,

- How print media can integrate this elements in creating future management strategy for advertising activities having in mind the importance of these revenue source for their budgets.

\section{RESEARCH SAMPLE}

Belgrade daily newspaper industry is currently undergoing a much-needed transformation, battered and distressed by a severe recession, declining advertising revenues, major shifts in consumer behavior and emerging disruptive technologies. As a result, we have seen some major media companies face with the burden of heavy debts, while the others are still experimenting with new survival formulas to restore the equation between newspaper content and earnings. Moreover, Serbian print media are facing severe digitalization process, and every day more of them are becoming viral and providing online version of the same media for their consumers.

The performed analyses included ten daily newspapers with national coverage: Politika, Večernje novosti, Danas, Blic, Alo, Kurir, Informer, Naše novine, Sportski žurnal and Sport. The research was performed during two months period in September-October 2013. The analyzed newspapers were divided in three categories: informative press (Politika, Večernje novosti, Danas) specialized press (Sportski žurnal and Sport), and tabloids (Blic, Kurir, Alo, Informer and Naše novine). In accordance with this categorization the research results are commented (Bubanja, 2014).

\section{COMMERCIAL CONTENT IN BELGRADE DAILY NEWSPAPERS}

Serbian advertising market is one of the poorest in Europe and in the region (average worth is about 170 million Euros in the last three years). During the 2008, the advertising market was 2.5 times lower than the market in Slovenia, and in 2011 about 50 million lower than in Croatia. The share of print media in Serbian ad market is around 23\%, which is also behind the European average. The Serbian online ad market is still in the phase of development, but advertisers are increasingly investing in the Internet media and are becoming more interested in global advertising solutions. Rich media templates have become more popular, as well as mobile and video banners. Although the resources are limited, advertisers are trying to keep in track with the global trends (Gemius, 2014).

Having all this in mind, daily newspapers on Serbian advertising market have very challenging task. The performed research of Belgrade daily press showed that there was a small number of commercials during two-month study, total 3.806 commercials, that was around 60 commercials per day for 10 newspapers that were included in the sample. Tabloids had the most commercials, around $59 \%$ of total number in analyzed period. In the second place was the informative press, while the least advertising content had specialized daily newspapers (Table 1).

\section{Table 1: Percentage of commercials contents in different types of newspapers

\begin{tabular}{|l|c|}
\hline Newspaper types & Percentage \\
\hline Tabloids & $58,7 \%$ \\
\hline Informative press & $34,5 \%$ \\
\hline Specialized press & $6,8 \%$ \\
\hline All (3806 commercials ) & $100 \%$ \\
\hline
\end{tabular}

Source: Author based on performed research

If we analyze commercials in every print media separately, we can conclude that "Kurir" had the most commercials, then "Večernje novosti", and on the third place was "Blic". The smallest number of commercials had sport press. In ten newspapers in our sample, there were only 6 commercials per newspaper per day. In Table 2 is presented total number of commercials in every newspaper during two months research.

Table 2: Total number of commercials in analyzed sample by each newspaper

\begin{tabular}{|l|c|}
\hline Newspaper & Number of commercials \\
\hline Alo & 265 \\
\hline Kurir & 721 \\
\hline Informer & 334 \\
\hline Naše novine & 225 \\
\hline Politika & 294 \\
\hline Danas & 284 \\
\hline Večernje novosti & 734 \\
\hline Blic & 691 \\
\hline Sportski žurnal & 71 \\
\hline Sport & 187 \\
\hline *All & 3806 \\
\hline
\end{tabular}

Source: Author based on the performed research 
Key factors determining these results and modest number of commercials in Belgrade daily newspapers were found in the circulation rate and the price of advertising space. Beside them, media target groups and the audience, text and iconic advertising requirements and the size of the commercial space, were also the parameters that influenced the companies selection of a certain print media.

\section{A) Circulation}

General decline of newspaper circulation occurred between 2006 and 2010. For example, in North America circulation was lower for $20 \%$, and for $10 \%$ in Western, Central and Eastern Europe. In accordance with this global trend, the circulation of
Serbian press is also falling due to the crisis in print media on the world level, as well as, the situation on the domestic media market. Circulations in our country have been monitored since 2007 by the Agency ABC Serbia (Audit Bureau of Circulations Serbia), but only for 42 out the 306 printed editions (Matić, 2012).

In our sample, the largest circulation had dailies: "Kurir", than "Večernje novosti" and on the third place was "Blic". Based on this statistics we can conclude that "Kurir" and "Večernje novosti" dominated as representatives of the tabloids and informative press (Table 3). Sport specialized newspapers had significantly lower circulation, which is in line with the character of these media that have a specific target group and whose audience is more carefully determined.

Table 3: Circulation of analyzed daily press

\begin{tabular}{|l|l|}
\hline Media & Circulations (average number of issues) \\
\hline Alo & 118.461 (Source: ABC Serbia, 2012) \\
\hline Kurir & 182.000 (Source: Author based on performed research) \\
\hline Informer & 112.586 (Source: Author based on performed research) \\
\hline Naše novine & 70.000 (Source: Author based on performed research) \\
\hline Blic & 115.779 (Source: ABC Serbia, 2012) \\
\hline Večernje novosti & $\begin{array}{l}145 / 150.000 \\
\text { (http://www.novosti.rs/vecernje novosti/o nama/o nama.40.html- 22.12.2013) }\end{array}$ \\
\hline Politika & 120.000 (Source: Author based on performed research) \\
\hline Danas & 70.000 (Source: Author based on performed research) \\
\hline Sportski žurnal & 30.000 (http://www.zurnal.rs/2010/06/13/impresum/index.html-22.12.2013.) \\
\hline Sport & 30.000 (http://www.sport.novosti.rs/ -22.12.2013.) \\
\hline
\end{tabular}

*Some data about circulation cannot be considered fully valid, because the author submitted by the media on request, but it is assumed that these are approximate figures.

\section{B) Advertising space price}

Real market position of daily press and its popularity is in accordance with circulation and the advertising space price. The price level of advertising space is in direct correlation with circulation rate. This means that newspapers with the highest circulation can have the highest advertising space prices.

It is generally believed that lower prices of advertising space will attract more advertisers in certain paper. The research results proved that in the case of Belgrade daily newspapers those with the highest circulation rate were the most attractive for advertisers although they had the highest price of advertising space. In our sample "Kurir" (circulation 182.000; advertising price per $\mathrm{mm} 260$ din) and "Večernje novosti" (circulation 150.000, advertising price per $\mathrm{mm} \mathrm{186)}$ attracted the highest number of advertisers (Table 4). Concerning the newspaper type, tabloids had higher prices of advertising space than informative press. Specialized sports newspapers had the same prices of advertising space as the informative press.

\section{SELF-PROMOTION IN BELGRADE DAILY NEWSPAPERS}

In literature, self-promotion is defined as an unpaid advertising content. For print media self-promotion is the main way to get a high range of readership and to attract new audiences to newspapers. There is always a possibility for print media to commercialize in other media, but those commercials are not that effective and do not reach the targeted group. Self-promotional messages must be in line with other promotional activities of certain newspaper and have to offer the audience the same promises that already had attracted their consumers' affection. Only in that way the invested money is properly used. Good self- 
promotion in print media can increase the price of advertising space (Eastman et al., 2004).

Table 4: Prices in dinars for advertising space in the analyzed press

\begin{tabular}{|l|c|c|c|}
\hline Media & $\begin{array}{c}\text { Price for the } \\
\text { whole page }\end{array}$ & $\begin{array}{c}\text { Price for any } \\
\text { page per mm }\end{array}$ & Remark \\
\hline Alo & 199.000 & 115 & Color \\
\hline Kurir & 355.000 & 260 & Color \\
\hline Informer & 200.000 & 125 & Color \\
\hline Naše novine & 220.000 & 165 & Color \\
\hline Blic & $250.000 / 380.000$ & $145 / 225$ & Lower prices b/w \\
\hline Večernje novosti and Sport & $224.000 / 347.000$ & $120 / 186$ & Lower prices b/w \\
\hline Politika and Sportski žurnal & 185.000 & 93 & Color $+50 \%$ \\
\hline Danas & $89.000 / 142.000$ & $49 / 78$ & Lower prices $\mathrm{b} / \mathrm{w}$ \\
\hline
\end{tabular}

Source: Author based on performed research

The results of performed analyses showed two self-promotion contents per newspaper per day. For two months period in ten analyzed newspapers were 1.037 self - promotion contents. Out of this amount around $41 \%$ percent were in informative press, $54 \%$ in tabloids, and $4 \%$ in specialized press (Table 5).

Table 5: Percentage of self-promotion contents in different types of newspapers

\begin{tabular}{|l|c|}
\hline Daily newspapers & Self-promotion \\
\hline Tabloids & $54,3 \%$ \\
\hline Informative press & $41,5 \%$ \\
\hline Specialized press & $4,2 \%$. \\
\hline All (1037) & $100 \%$ \\
\hline
\end{tabular}

Source: Author based on performed research

Regarding self-promotion contents, the situation in specific daily newspapers was the following. "Ringler Axel Springer" publications (Alo and Blic) were dominating in terms of presenting their own issues and self - promotions (Table 6). For specialized press the number of self-promotions depended on the editorial board of every newspaper, causing that "Sportski žurnal" had no self-promotion, but "Sport" had.

Self-promotion is considered as an effective way of attracting new readership, which is necessary for the survival of newspapers. In fact, the number of self-promotion ads is rising and their contents and forms are so advanced that they are becoming equal to commercials. This opens two questions. The first one is whether self-promotion steals readers' attention from the current commercial contents, what can affect decreasing interest of advertisers for certain newspaper. The second question is dilemma, if increasing number of selfpromotions indicates in the same time an inability of a newspaper to sell its complete advertising space, lowering possibilities for earnings in this profit source.

Table 6: Total number of self-promotions in analyzed sample by each newspaper

\begin{tabular}{|l|c|}
\hline Daily newspaper & $\begin{array}{c}\text { Number of } \\
\text { self - promotions }\end{array}$ \\
\hline Alo & 202 \\
\hline Kurir & 1 \\
\hline Informer & 0 \\
\hline Naše novine & 0 \\
\hline Politika & 126 \\
\hline Danas & 74 \\
\hline Večernje novosti & 230 \\
\hline Blic & 360 \\
\hline Sportski žurnal & 0 \\
\hline Sport & 44 \\
\hline *All (100\%) & 1037 \\
\hline
\end{tabular}

Source: Author based on performed research

\section{CHARACTERISTICS OF COMMERCIAL AND SELF-PROMOTION CONTENTS IN BELGRADE DAILY NEWSPAPERS}

In performed research the average commercial in Belgrade daily newspapers was of a small size, located at the bottom of the right page, with no title, and consisted of texts and images. The text was brief, and mainly contained the slogan or the phrase: "Special offer" and "Super price". The photo was in color and had a symbolical meaning. Public figures and prices were rarely parts of a commercial content. This type of commercial was repeated regardless of the type of daily newspapers. Advertisers commercialized in a small format, but also in a format of a quarter or a half of the page. Small commercials were the most popular, but they were not repeated during the working week (Vidas-Bubanja \& Bubanja, 2015). 
Advertisers usually did not have enough funds to pay for a big promotion format and they usually used small commercials format. Just a small number of advertisers used a format of a half and a quarter of the page and these were usually financially powerful companies that were able to advertise several times during the working week or several times even within a single newspaper.

Self-promotion was usually published in a small format, because newspapers still wanted to rent free space to those who would actually pay for it.
Belgrade newspapers published their selfpromotion contents at the bottom of the right page. When self-promotions were repeated several times during the week, they were placed alternatively on the right page and on the left page.

The results showed that in the case of Belgrade press there were 4-5 times more commercials than self-promotions (Figure 1). The number of selfpromotions was constantly growing, which was most indicative in tabloids, followed by informative press.

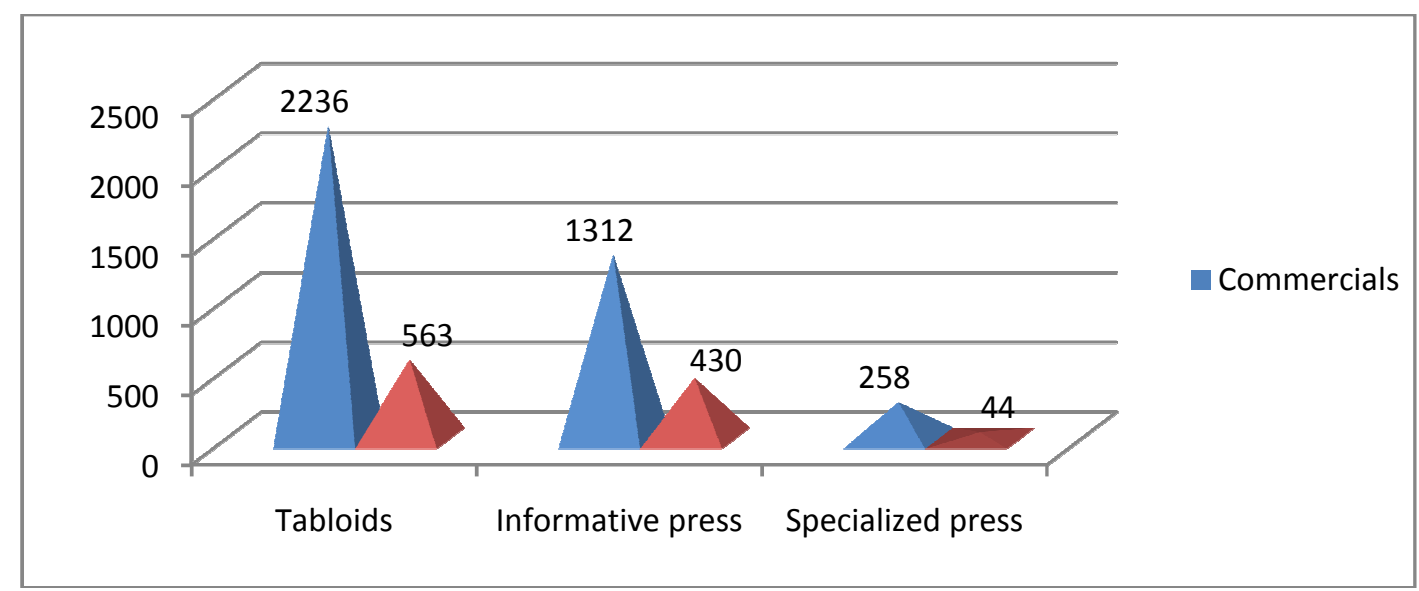

Figure 1: Commercials and self-promotions in different types of newspapers

The biggest problem was in similarity between self-promotions and commercials. Without deeper analyses customer's eye could not make a difference between these two contents. Texts and photos were similar, or sometimes even more attractive in the case of self-promotions.

\section{COMMERCIAL AND SELF-PROMOTION CONTENT IN ONLINE VERSIONS OF BELGRADE DAILY NEWSPAPRES}

This transition of Belgrade daily newspapers to online version is closely connected with the increasing number of the Internet users in Serbia, around $3.5 \mathrm{~m}$. They spend average $13 \mathrm{~h}$ online per week by IAB Europe research from 2012 (Table 7). The use of the Internet in Serbian society keeps growing on daily basis especially among young generations, who are more mobile and informed, and who are searching for free information on the network (IAB.Europe, 2012b).

From ten analyzed national newspapers, eight of them had their online versions, and nine of them had their Facebook and Twitter accounts. On other social networks such as Pinterest, Instagram, Google + only some of them had their profiles which were not regularly updated. However, by Gemius the most popular websites in 2013 were online versions of national newspapers that were providing news from different spheres of life. The leader in 2013 in the online market was www.blic.rs, which is news portal that reached $53 \%$ of Internet population, and on the second place was www.kurir-info.rs, which is also a newspaper online portal that is providing news. After them the best ranked were www.b92.rs, www.telegraf.rs, www.24sata.rs, www.novosti.rs, etc. (Gemius, 2014).

There were more promotion contents in online than in print version of the same newspaper. On daily basis, these web portals were presenting 43 commercial and 52 self-promotion contents. That was around 4 commercials and 5 self-promotions per newspaper in their on line edition. Specialized press was again in the worst position and had around 5 times fewer commercials than other daily newspapers in online form. In order to use increasing numbers of daily visits to their portals newspapers are raising the number of selfpromotions with the aim to provide more readership. The effect is even greater because 
online readers are active users and not just the passive audience.

Table 7: Use of Internet and media consumption landscape in Serbia

\begin{tabular}{|c|}
\hline $\begin{array}{l}\text { Facts and figures for } 2014 \\
\text { - } 3.500 .047 \text { Internet users in Serbia - penetration rate } 48 \% \\
-3.800 .000 \text { Active Facebook users - penetration rate } 52 \% \\
-\quad 9.138 .000 \text { Active mobile subscription - penetration rate } 128 \% \\
-\quad 2.900 .000 \text { Active mobile broadband subscription, penetration } 40 \% \\
-\quad 2.400 .000 \text { Active social media users accessing social media on a mobile device - penetration } 33 \%\end{array}$ \\
\hline $\begin{array}{l}\text { The Serbian media consumption landscape } 2012 \\
\text { - Use per week: TV } 16,9 \mathrm{~h} \text {, online } 13 \mathrm{~h} \text {, radio } 13,1 \mathrm{~h} \text {, newspapers } 4,4 \mathrm{~h} \text {, magazines } 3,5 \mathrm{~h} \\
-48 \% \text { of Serbian Internet users watch TV online monthly } \\
-61 \% \text { of Serbian Internet users listen to the radio online monthly } \\
-83 \% \text { of Serbian Internet users read news online monthly } \\
-52 \% \text { of Serbian Internet users visit news websites every day } \\
-99 / \text { of Serbian Internet users communicate through email } \\
-89 \% \text { of Serbian Internet users have used a personal or professional Social media website }\end{array}$ \\
\hline
\end{tabular}

Source: (Kemp, 2014; RZS, 2014; IAB. Europe, 2012).

The research results showed similarity of commercial contents in all newspaper type no matter whether we talk about print or online edition. By comparing them it could be concluded the following: content types were repeated, there was a lack of variety of products and services, and narrowed choice was offered to potential buyers. The reasons for this were also connected with limited company budgets for commercials and the situation that the audiences of the different daily newspapers had the same preferences and tastes. In this way, newspapers created one public and a uniform product offer (Bubanja, 2014).

The research also showed that advertisers were choosing the same formats in online edition of different newspapers, and they placed their ads in the specific page type. If advertisers' desired detailed processing of ad messages by consumers, they usually placed their commercials on destination pages, even though the access might be more difficult than on navigational pages. The research identified several physical characteristics, such as visibility and time delay, as important factors in online advertising that affect perceived advertising level. Also the value of an audience to advertisers was determined by its receptiveness to advertising. Such emphasis on advertising acceptance signified the voluntary nature of media consumption and the importance of creating a receptive media environment for advertisers.

There was no regularity in repetition of commercial contents in online form. The characteristics of the texts and the photos were the same for online and print edition of newspapers commercials. The only difference was that in online world all commercials were in color no matter if they were having a photo, or not.

\section{CONCLUSION ABOUT RESEARCH RESULTS}

Statistics proves that the media and publishing industry is undergoing a massive transformation thanks to the rise of digital, which has made traditional revenue models based solely on subscriptions and advertising sales virtually obsolete. Small number of commercials during two-month study of the selected Belgrade daily newspapers (online and print version) was not a good indicator concerning advertising activities as a revenue source for their budgets. Comparing with western developed economies where ad resources represent up to $80 \%$ of newspaper budgets, in Serbia this percentage is more modest, around $20 \%$ (Bubanja, 2014).

Based on these tendencies there is an urgent need for the creation of new print media management strategy for Belgrade dailies that will acknowledge digitalization processes and find new revenue streams and growth opportunities. The performed analyses indicate the following:

- The number of commercials in the print newspapers format dropped, while the number of ads in online version of daily Belgrade newspapers was in constant rise,

- The commercials were the most present in tabloids, 
- The high circulation rate was a key determinant for advertisers despite more expensive advertising space,

- The number of self-promotion activities was also in rising, though there were still more commercials than self-promotions in the paper per day,

- There was growing competition between print and online version of the same newspaper concerning the commercial content.

The presented results clearly indicate that Serbian print media in their management strategy have to include new advertising trends influenced by the Internet and promotion capabilities of digital media by devoting attention to their online versions of the daily papers in order to provide rising advertising income for their budgets.

Newspapers are going through meager changes intending to adapt to business conditions in the digital environment. This is due to the need of print media to satisfy users who are spending more time on the Internet. In this way dailies will keep advertisers in their media and provide resources for their survival.

The analyses show that self-promotion contents have to be integrated in advertising strategy of newspapers very carefully in order not to jeopardize advertiser's interest in certain press. Smart use of self -promotions and its quality can contribute even to the higher price of advertising space. Concerning the newspaper type, tabloids were most attractive for advertisers to place their commercials. That is closely connected with the offered type of products and services, and the tabloid audience, who is more interested in sensationalism and pompous titles, than in accurate and objective information. In order to raise the number of commercials, informative press needs to pay more attention to create content and commercials in accordance with preferences of their target groups. Specialized press can expect commercial content only closely connected to their thematic sphere.

Print media management has also to take in consideration the general situation of the Serbian economy and society burdened with reform and transition processes, as well as economic recession and stagnation. There is significant reduction of producers' capability to allocate funds for advertising purposes. Within the reduced budgets for marketing activities and limited resources, producers in Serbia choose more cautiously the media for advertising. They select media that can bring commercial message to the biggest number of potential buyers creating fierce competition between print and digital media (Vidas-Bubanja \& Tanasković, 2012)

Along with this, complete society in Serbia has some new characteristics as the high unemployment rate and lower monthly income force people to use the biggest part of their salary to satisfy their basic needs. Purchase of daily press became a luxury that many cannot afford. Nowadays, middle and upper classes is still buying print media, but there is a growing number of readers that prefer to use online services for their news consumption.

It can be concluded that Belgrade print media need to include the Internet in their future advertising development strategy. The research results and current situation in Serbian economy and the society support the urgency for the creation of new print media management strategy based on click and brick business model. This means that only cooperation and synergy of print and digital versions of newspaper can create the most effective way of presenting promotional contents to modern and choosy buyers.

\section{REFERENCES}

Bubanja, I., (2014). Newspapers in Modern Commercial Practice - monograph, Belgrade, Zaduzbina Andrejevic (in Serbian).

Eastman, S., T., Ferguson, D. A., and Klein, R. (2004). Promotion \& marketing for broadcasting, cable and the web, Belgrade, Clio (in Serbian).

Gemius (2014). Online Landscape South-East Europe, March, http://www.slideshare.net/Gemius_com/gemiusknowledge-southeasteurope-36738967.

IAB.Europe (2012a). European Media Consumption, from http://www.iabeurope.eu/research-and-papers.

IAB.Europe. (2012b). Serbia launch Presentation Summary, from http://iab.rs/mediascope-europe2012/

Jefkins, F. (2003). Advertising. Belgrade: Clio.

Kotler, P. (2004). Marketing insights from A to Z. Novi Sad: Adizes.

Matić, J. (2012). The structural causes of the crisis of newspapers in Serbia Yearbook Faculty of Political Science (pp. 167 - 182). Belgrade: FPN.

Patel, A. (2010). The Survival of the Newspapers in the Digital Age of Communication. from New York University http://www.stern.nyu.edu/sites/default/files/assets/do cuments/con_043010.pdf

Potter, J. W. (2011). Media literacy. Belgrade: Clio (in Serbian). 
RZS. (2014). Use of ICT in Serbia, Year Report. Belgrade, Serbia.

Vidas-Bubanja, M., \& Tanasković, G. (2012). EMarketing. Belgrade: BPŠ

Vidas-Bubanja, M., \& Bubanja, I. (2015, May 25 - 29). Internet challenges for print media advertising practice - case of Belgrade daily newspapers. Paper presented at the 38th International convention on information and communication technology,

electronics and microelectronics, MIPRO, Opatija, Croatia.

Kemp, S. (2014). Social, Digital \& Mobile Worldwide Report Retrieved from

http://wearesocial.net/blog/2014/01/social-digitalmobile-worldwide-2014/ 